\title{
Metastatik kemik lezyonlarında radyoterapinin yeri
}

\author{
Radiotherapy in bone metastases
}

\author{
Korhan Özkan, Tarık Sarı
}

S. B. İstanbul Medeniyet Üniversitesi Göztepe Eğitim ve Araştırma Hastanesi, Ortopedi ve Travmatoloji Anabilim Dalı

Solid organ metastazları, en sık akciğerlere sonra karaciğere ve üçüncü olarak da kemiğe olur. Kemik metastazları olan kişi, hayatının sonuna gelmiş bir hasta olarak değerlendirilmemelidir. Özellikle son zamanlarda, hem kemoterapi hem de radyoterapideki gelişmelere bağlı olarak, hastalar uzun yıllar yaşayabilmektedir. Soliter kemik metastazlı hastalarda, primer kemik tümörlü hastalarda olduğu gibi, iyileşme dahi olabilir. Kemik metastazı olan hastalara uygulanan radyoterapinin amacı; hastanın hayat kalitesini arttırmak, iskelet fonksiyonlarının devamını sağlamak, ağrı kesici kullanımını azaltmak ve mümkünse ortadan kaldırmaktır. Bunları başarmak için; tümör progresyonunu, patolojik kırık oluşumunu ve spinal kord basısını engellemek ya da ortadan kaldırmak, ana amaçlar arasında yer alır. Metastatik kemik lezyonlu hastaların tedavisinde multidisipliner yaklaşımın önemi unutulmamalı ve plansız cerrahi girişim yapılmamalıdır. Hastalarda uygulanacak tedavi yaklaşımında radyoterapi; uzun kemiklerin metastatik lezyonlarında Mirels'in skorlama sitemine göre, vertebral metastazlarda ise NOMS çatısına göre belirlenmelidir. Ayrıca, metastazlı hastalarda uygulanan radyoterapi, kırık kaynamasını engellemek bir yana, tümör hücrelerini yok ederek kaynama için uygun ortam da hazırlar.

Anahtar sözcükler: kemik metastazları; radyoterapi
Solid organ metastases most commonly occur in the lungs, then in the liver, and third in the bone. A patient with bone metastases should not be considered as a person who has come to the end of his life. Patients can survive for many years, especially due to recent developments in both chemotherapy and radiotherapy. Healing may occur in patients with solitary bone metastases as in patients with primary bone tumors. The aim of radiotherapy in patients with bone metastasis is to improve the quality of life, to maintain skeletal functions, and to reduce and if possible to stop the use of painkillers. To accomplish these, the main objectives are to prevent or eliminate tumor progression, pathological fracture formation, and spinal cord compression. The importance of multidisciplinary approach in the treatment of patients with metastatic bone lesion should not be forgotten, and no surgery should be performed without such a treatment plan. Radiotherapy, as a treatment modality in patients who have metastatic lesions of the long bone, should be planned according to the Mirels' scoring system whilst in patients with vertebral metastasis according to the NOMS framework. In addition, radiotherapy in patients with metastases, aside from preventing fracture union, destroys tumor cells and therefore provides a suitable environment for union.

Key words: bone metastases; radiotherapy olid organ metastazları en sık akciğerlere, sonra karaciğere ve üçüncü olarak da kemiğe olur. Kemik metastazları olan kişi, hayatının sonuna gelmiş bir hasta olarak değerlendirilmemelidir. Özellikle son zamanlarda, hem kemoterapi hem de radyoterapideki gelişmelere bağlı olarak, hastalar uzun yıllar yaşayabilmekte ve soliter kemik metastazlı hastalarda, primer kemik tümörlü hastalarda olduğu gibi iyileşme dahi olabilmektedir.
İtalya'dayılda 35.000, Amerika Birleşik Devletleri'nde ise yılda 400.000 yeni kemik metastazlı hasta teşhis edilmektedir. Bu metastazların \%85'ini meme, prostat ve akciğer kanserleri oluşturmaktadır. Yine, kemik metastazlı hastaların \%20'sinde metastaz ilk bulgu olarak ortaya çıkmaktadır. ${ }^{[1]}$

Bu hastalarda hem cerrahi girişim, hem kemoterapi hem de radyoterapi planlaması yapılırken en önemli unsurlardan biri de yaşam beklentisinin ortaya

- Iletişim adresi: Prof. Dr. Korhan Özkan, S. B. İstanbul Medeniyet Üniversitesi Göztepe Eğitim ve Araştırma Hastanesi, Ortopedi ve Travmatoloji Anabilim Dalı, Eğitim Mahallesi, Dr. Erkin Cad. 34722, Kadıköy, İstanbul Tel: 0532 - 2242448 e-posta: korhanozkan76@gmail.com

- Geliş tarihi: 31 Ağustos 2019 Kabul tarihi: 22 Ekim 2019 


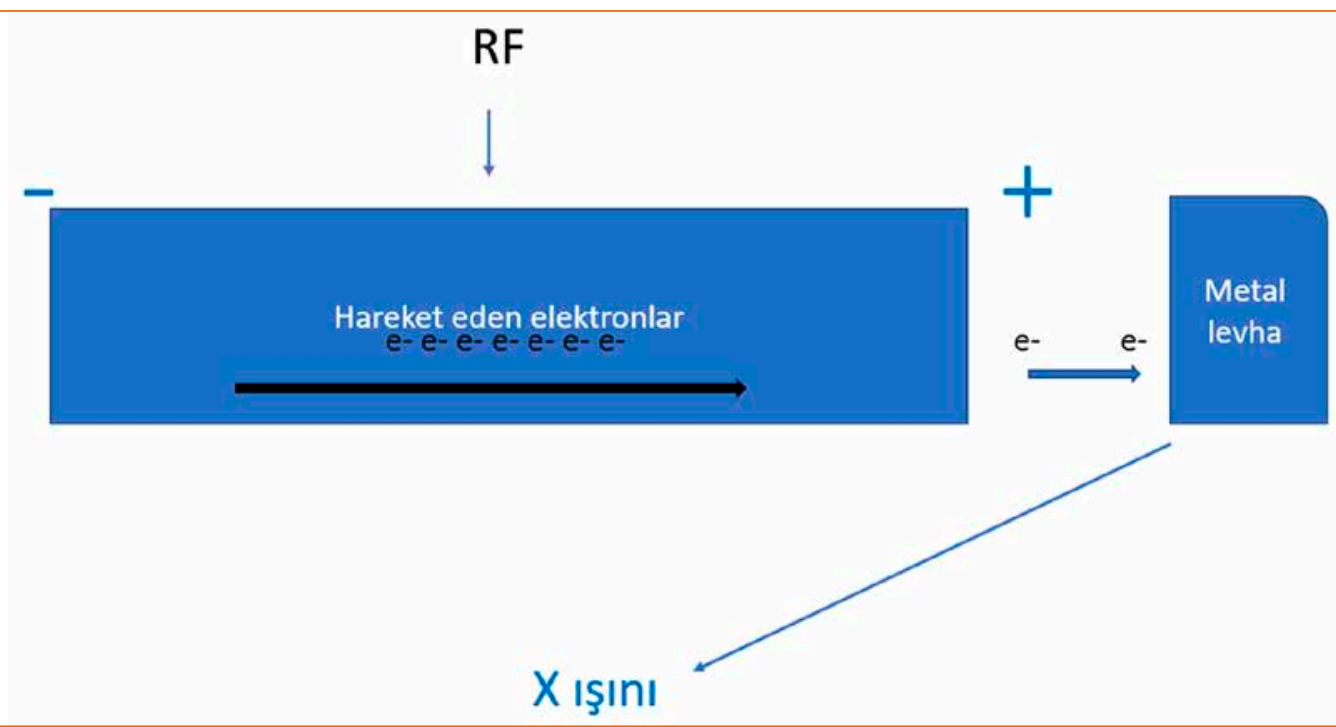

Şekil 1. Elektronlar negatif kutuptan pozitif kutba doğru hareket ederken, dışarıdan radyofrekans dalgaları (RF) verilerek bu elektronlar çok yüksek hızlara ulaştırılır. Yüksek hızlı elektronlar metal bir levhaya çarptırılarak X ışınlarının ortaya çıkması sağlanır.

konmasıdır. Özellikle Forsberg ve ark.'nın son yıllarda popülarize ettiği PATHFx yöntemiyle, hastaların olası yaşam süreleri önemli doğruluk oranıyla ortaya konulabilmektedir. Bunun için 10 prognostik özellik belirlenmiştir ${ }^{[2-4]}$ :

1) Cerrahi sırasındaki yaş

2) Cinsiyet

3) Cerrahi endikasyon (patolojik ya da oluşmak üzere olan kırık)

4) Tek ya da çoklu metastaz

5) Cerrahın hastayla ilgili yaşam beklentileri

6) Organ metastazlarının varlığı ya da yokluğu

7) Lenf nodu metastazlarının varlığı ya da yokluğu

8) Lenfosit sayısı

9) Ameliyat öncesi hemoglobin değeri

10) Hastanın primer onkolojik tanısı

Metastazlara bağlı iskelet sistemini ilgilendiren olaylara baktığımızda; ağrı, patolojik kemik kırıkları, spinal kord basısı ve hiperkalsemi ön sıralarda bulunmaktadır. Tedavimizde amaç, bu komplikasyonları engellemek ya da ortadan kaldırmaktır. Radyoterapi işte bu noktada giderek artan bir rol oynamaktadır. Özellikle teknolojik gelişmelere paralel olarak da, tedavi etkinliğinde önemli gelişmeler gözlenmektedir.

Radyoterapide kullanılan $X$ ve gama ışınları aslında birer elektromanyetik enerji çeşididir. Radyasyon tedavisi etkinliğini, direkt olarak DNA'da hasar yaratarak, indirekt olarak ise çeşitli serbest radikaller oluşturup bunlar üzerinden hücre DNA hasarı yaparak gösterir. ${ }^{[5]}$

Klinik radyoterapi uygulaması üç şekilde olur:

1) Eksternal ışıma radyasyonu (konvansiyonel $X$ ışını kullanılarak yapılan radyoterapi)

2) Brakiterapi

3) Radyonükleotid tedavisi

Kemik metastazı olan hastalara uygulanan radyoterapinin hedefi; hastanın hayat kalitesini arttırmak, iskelet fonksiyonlarının devamını sağlamak, ağrı kesici kullanımını azaltmak ve mümkünse ortadan kaldırmaktır. Bunları başarmak için; tümörün ilerlemesini, patolojik kırık oluşumunu ve spinal kord basısını engellemek ya da ortadan kaldırmak gerekir.

Konvansiyonel radyoterapide kullanılan $X$ ışınını elde etmek için; elektronlar negatif kutuptan pozitif kutba doğru hareket ettirilirken, radyofrekans dalgaları gönderilerek bu elektronların hızları arttırılır ve hızlanmış elektronlar metal levhaya çarptırılır. Bu yüksek hızla çarpmanın etkisiyle de metal levhadan X ışını (X-ray) yayılır. Bu düzeneğe "linear accelarator" denilir (Şekil 1).

Metastatik kemik lezyonlarında radyoterapi dozuna baktığımızda, genel olarak;

$8 \mathrm{~Gy} \rightarrow$ Tek doz

20 Gy $\rightarrow 5$ Seansta (seans başına 4 Gy)

$30 \mathrm{~Gy} \rightarrow 10$ Seansta (seans başına 3 Gy) 

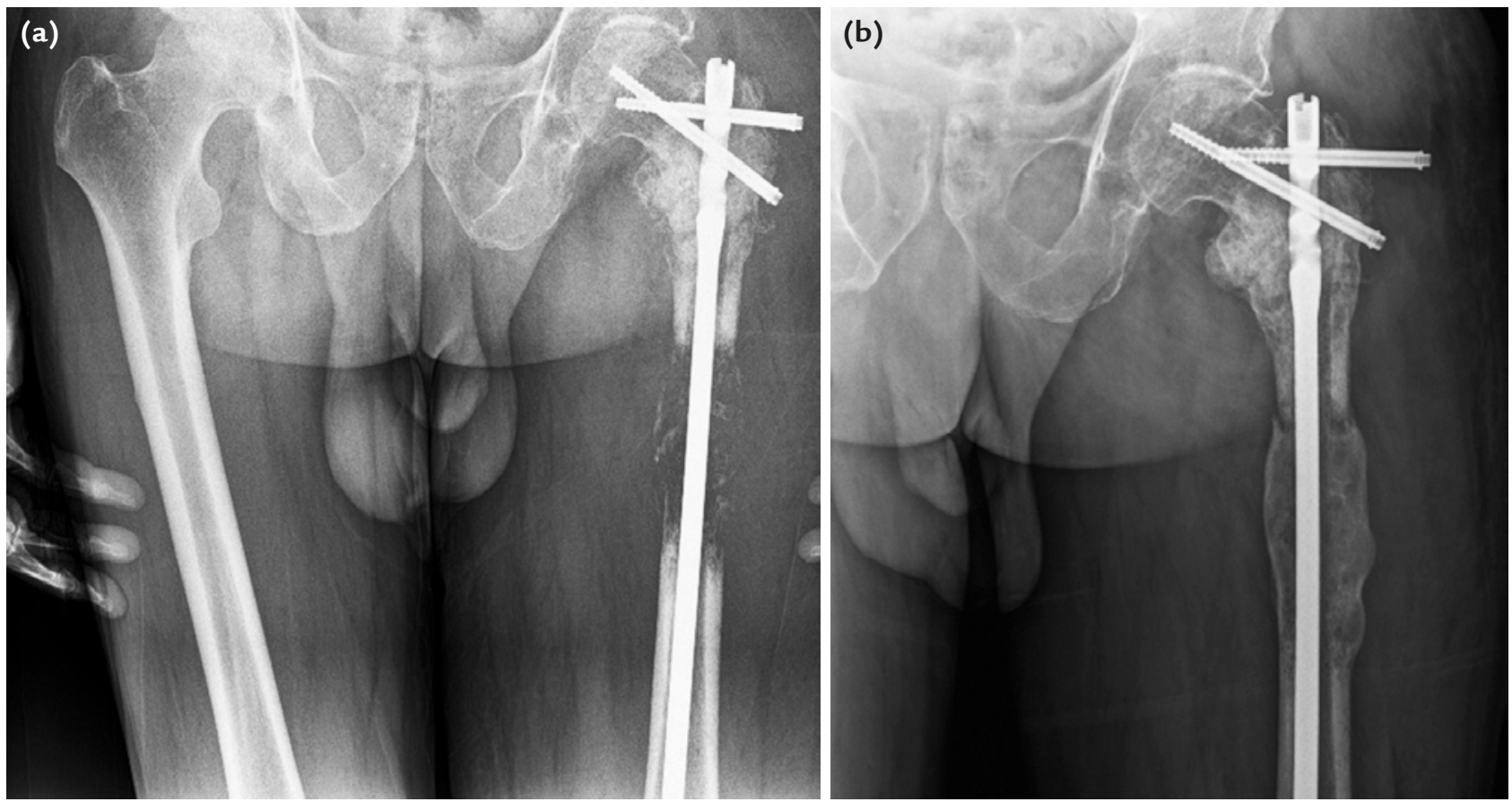

Şekil 2. Renal hücreli karsinom metastazı olan hastada çivi ile internal tespit sonrası radyoterapi verilmesi ve kallus oluşumu (20 Gy / 5 seans).

olarak verilmektedir (1 Gy [Gray]; ışılanan maddenin her kilogramına bir jul enerji veren radyasyon miktarıdır). ${ }^{[6-8]}$ Tek dozluk tedavi çoğunlukla, genel durumu bozuk olan ve mobilitesinde güçlük çekilen hastalarda tercih edilir. Ancak, tek doz alan hastalarda ilerleyen dönemlerde tekrar radyoterapi gerekliliği 2,6 kat daha fazladır. ${ }^{[9]}$ Genel olarak, radyoterapi sonrası hastaların \%85'inde ağrı yanıtı alınır, tam ağrı yanıtı hastaların ancak \%30'unda olur. Radyoterapi sonrası ağrının azalması tümör hücrelerinin sayısının azalmasının yanı sıra inflamatuvar hücre sayısındaki azalmaya da bağlıdır. Ağrı yanıtı genellikle ilk dört haftada maksimuma ulaşır ve ortalama 15 hafta sürer. ${ }^{[10-12]}$

Uzun kemik metastazlarında tedaviyi planlarken, bazı tartışmalara rağmen, çoğunlukla Mirels skorlama sistemi kullanılmaktadır. ${ }^{[13]}$ Kemik metastazlı hastanın skoru "7" ve altında ise genellikle radyoterapi tek başına tedavide kullanılırken, " 8 " ve üzerindeki puanlarda cerrahi, sonrasında ise radyoterapi tercih edilmektedir.

Uzun kemiklerde patolojik kırık nedeniyle uygulanan cerrahi tespit ya da protezle rekonstrüksiyon sonrası radyoterapi; makroskopik ya da mikroskopik olarak geride kalan tümör hücrelerini yok etmek, tümör regresyonuna bağlı tekrar cerrahi ihtimalini azaltmak ve kemik kaynamasını sağlamak amacıyla uygulanmalıdır (Şekil 2).
Günümüzde sıklıkla, “CT scan” simülasyonunun uygulandığı üç boyutlu konformal radyoterapi yapılmaktadır. Böylece, çevre sağıklı dokulara verilen radyoterapi miktarı minimuma indirilirken, hedef tümörlü bölgenin asıl dozu alması sağlanabilmektedir. Diğer bir radyoterapi yöntemi ise son zamanlarda daha sık kullanılmaya başlanan stereotaktik radyoterapidir. Beyin cerrahisinde kullanılan bu yöntem "gamma knife" ile aynı prensiple çalışmakta olup, düşük enerjili çok sayıda ışını hedef noktada birleştirerek çok yüksek dozda bir enerjiye ulaşma prensibine dayanır.

Her bir fraksiyonda yüksek doz, yani 10 Gy'den fazla enerjinin hedef noktada birleştirilerek uygulanmasıyla, tümör hücrelerindeki DNA hasarının yanı sıra tümör vaskülaritesindeki azalma için direkt etki sağlanmış olur. ${ }^{[5]}$

Stereotaktik radyoterapi endikasyonları arasında; vertebra gövde lezyonları, lezyon çapının $5 \mathrm{~cm}$ 'den az olması, semptomatik spinal kord basısının bulunmaması ve hedef radyoterapi hacminde en fazla üç vertebra bulunması yer alır. Semptomatik spinal kord basısı varsa, stereotaktik radyoterapi ancak cerrahi olarak dekompresyon yapıldıktan sonra verilebilir; çünkü, spinal kordu hedef alan stereotaktik radyoterapide, geri dönüşümsüz miyelopati ve sinir arazı riski vardır. ${ }^{[14]}$ 


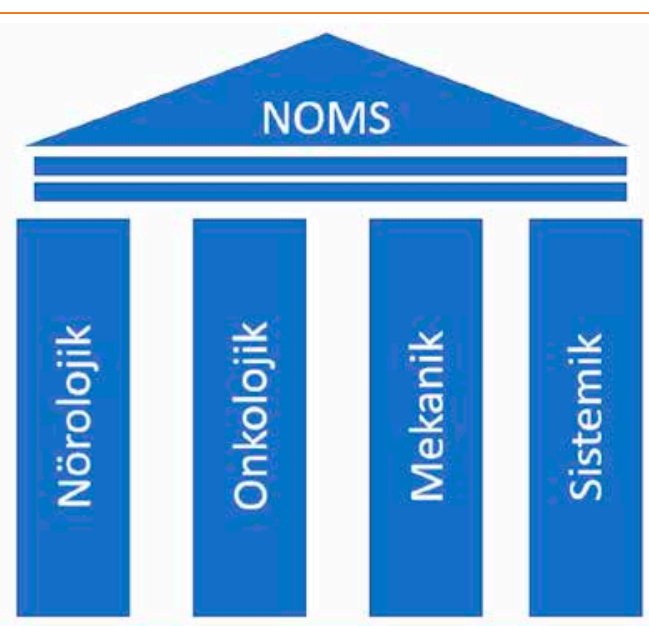

Şekil 3. Omurga metastazlarında tedaviye karar verirken NOMS çatısı; nörolojik (spinal kord basısına göre), onkolojik (metastaz yapan tümörün radyosensitivitesine), omurganın mekanik stabilitesine ve sistemik yani hastanın operasyonu tolere edip edemeyeceğine göre karar verilir.

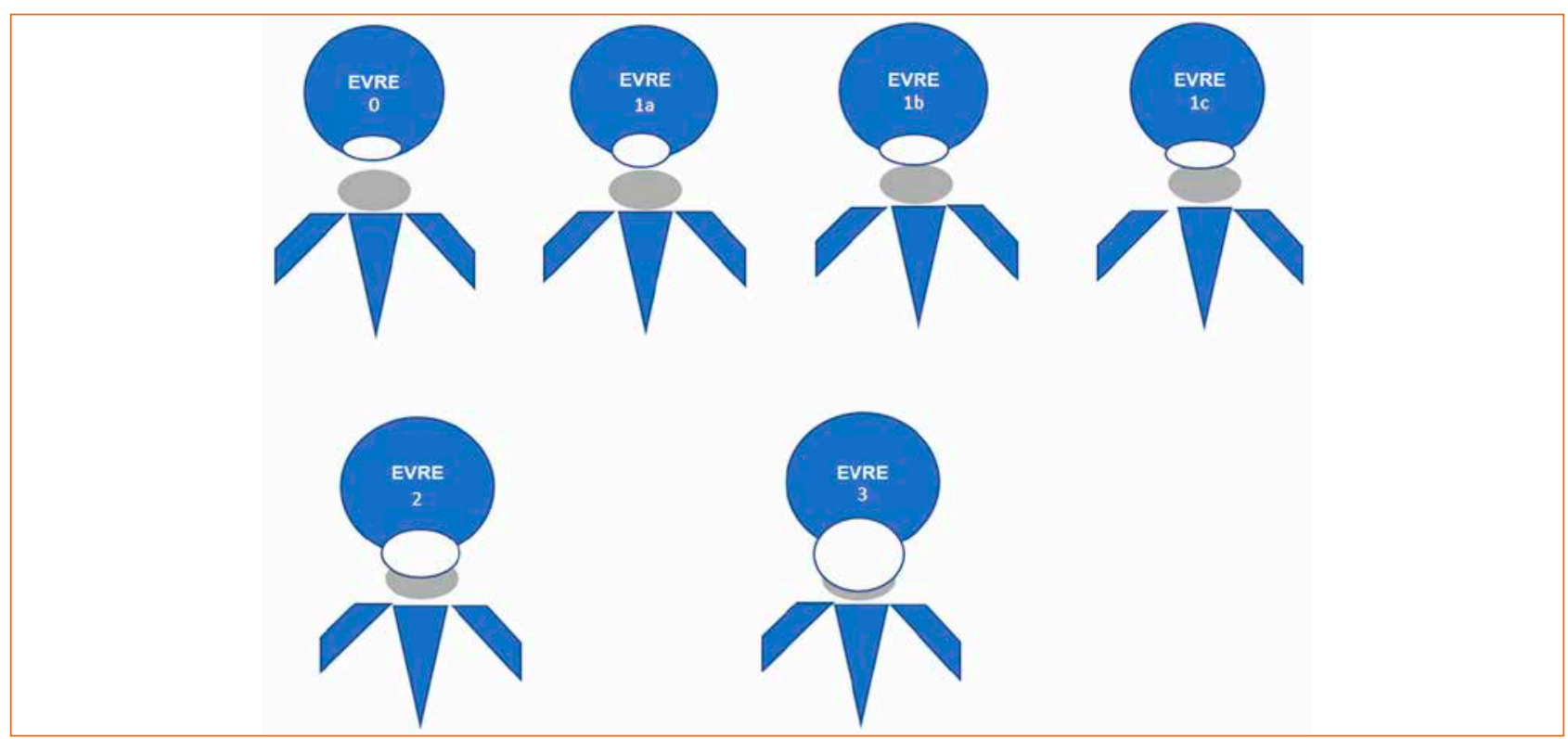

Şekil 4. Evre 0, sadece kemik tutulumu; Evre 1a, tekal sak deformasyonu olmadan epidural kompresyon; Evre 1b, kord teması olmadan tekal sak deformasyonu; Evre 1c, kord temasıyla birlikte tekal sak deformasyonu; Evre 2, Beyin-omurilik sıvısının bir kısmının korunmasıyla birlikte kord kompresyonu; Evre 3, beyin-omurilik sıvısının tamamen silinmesiyle birlikte kord kompresyonu (Evre 0-1c, düşük evre; Evre 2-3, yüksek evre olarak adlandırılır.)

Metastatik spinal kord kompresyonu; \%70 olasılıkla torasik, \%20 lomber ve \%10 servikal vertebrada meydana gelmektedir.

2013 yılında Laufer ve ark.'nın yayımladığı, The NOMS Framework (NOMS çatısı) adlı makale, spinal metastatik tümörlere yaklaşımda önemli yol gösterici kaynak olmuştur. ${ }^{[15]}$ Bu çatıda; hastalar nörolojik, onkolojik, mekanik ve sistemik durumlarına göre değerlendirilir (Şekil 3). Hasta nörolojik olarak, vertebral lezyonun spinal kord basısına göre, düşük ya da yüksek evreli olarak sınıflandırılır (Şekil 4). Onkolojik olarak ise tümör hücrelerinin radyosensitivitesi değerlendirilir. 
Meme ve prostat radyosensitivite olarak +++; akciğer, melanom ve tiroid ++; böbrek ise -'dir (Tablo 1).

Hastanın mekanik olarak spinal instabilitesi olup olmadığına, omurga instabilite neoplasti skoru kullanılarak; sistemik olarak cerrahiyi tolere edip edemeyeceğine ise, hastanın ECOG (Eastern Cooperative Oncology Group) ya da Karnofsky Performans skorlamasına göre karar verilir. ${ }^{[15]}$

\section{OLGU ÖRNEĞi}

Yedi yaşında metastatik servikal lezyonu olan hastada, yüksek evreli epidural spinal kord kompresyonu, instabil bir lezyon, radyosensitif bir tümör (Ewing sarkom) ve cerrahiyi tolere edebilecek genel durum mevcuttu. NOMS çatısına bu bilgiler yerleştirilerek hastanın tedavisi planlanmış ve posterior stabilizasyon sonrası konvansiyonel eksternal radyoterapi uygulanmıştır (Şekil 5).
Benzeri hasta grubuna, semptomatik spinal kord kompresyonu sonrası dekompresif cerrahi ve cerrahi sonrası üç boyutlu konformal ya da stereotaktik radyoterapi uygulanabilir. Dozlar 20 Gy (4 Gy/seans) ya da 30 Gy (3 Gy/seans) şeklindedir. Ancak, hastanın eşlik eden morbiditeleri nedeniyle opere edilemeyecek ya da kısa yaşam beklentisi mevcutsa, cerrahi uygulanmadan tek doz konvansiyonel radyoterapi de uygulanabilir. ${ }^{[5]}$

Hastaların \%50'sinde radyoterapi sonrası ortalama bir yılda ağrılar tekrar ortaya çıkabilir. Bu durumda, tek doz 8 Gy ya da seans başına 4 Gy olmak üzere 20 Gy tekrar radyoterapi verilebilir. Yine, radyoterapi almış hastaların \%40'ında radyoterapi sonrası ağrıda yeterli azalma olmayabilir, hatta cevapsızlık olabilir; bu durumda da, ilk radyoterapinin dört hafta sonrasında tekrar radyoterapi yapılmaya başlanabilir. ${ }^{[16]}$

Diğer bir radyoterapi yöntemi olan brakiterapinin, son zamanlarda konvansiyonel radyoterapideki gelişmelere bağlı olarak kullanımı azalmış olsa da, lokalize

Tablo 1. NOMS çatısı

\begin{tabular}{|c|c|c|c|c|}
\hline Nörolojik & Onkolojik & Mekanik & Sistemik & Karar \\
\hline $\begin{array}{l}\text { Düşük evreli epidural spinal kord } \\
\text { kompresyonu }\end{array}$ & Radyosensitif & Stabil & & Konvansiyonel radyoterapi \\
\hline $\begin{array}{l}\text { Düşük evreli epidural spinal kord } \\
\text { kompresyonu }\end{array}$ & Radyosensitif & Stabil değil & & $\begin{array}{l}\text { Stabilizasyon ve takiben konvansiyonel } \\
\text { radyoterapi }\end{array}$ \\
\hline $\begin{array}{l}\text { Düşük evreli epidural spinal kord } \\
\text { kompresyonu }\end{array}$ & Radyorezistan & Stabil & & $\begin{array}{l}\text { Stereotaktik } \\
\text { radyoterpi }\end{array}$ \\
\hline $\begin{array}{l}\text { Düşük evreli epidural spinal kord } \\
\text { kompresyonu }\end{array}$ & Radyorezistan & Stabil değil & & $\begin{array}{l}\text { Stabilizasyon ve takiben stereotaktik } \\
\text { radyoterapi }\end{array}$ \\
\hline $\begin{array}{l}\text { Yüksek evreli epidural spinal kord } \\
\text { kompresyonu }\end{array}$ & Radyosensitif & Stabil & & Konvansiyonel radyoterapi \\
\hline $\begin{array}{l}\text { Yüksek evreli epidural spinal kord } \\
\text { kompresyonu }\end{array}$ & Radyosensitif & Stabil değil & & $\begin{array}{l}\text { Stabilizasyon ve takiben konvansiyonel } \\
\text { radyoterapi }\end{array}$ \\
\hline $\begin{array}{l}\text { Yüksek evreli epidural spinal kord } \\
\text { kompresyonu }\end{array}$ & Radyorezistan & Stabil & $\begin{array}{l}\text { Cerrahiyi tolere } \\
\text { edebilir }\end{array}$ & $\begin{array}{l}\text { Dekompresyon/stabilizasyon ve takiben } \\
\text { stereotaktik radyoterapi }\end{array}$ \\
\hline $\begin{array}{l}\text { Yüksek evreli epidural spinal kord } \\
\text { kompresyonu }\end{array}$ & Radyorezistan & Stabil & $\begin{array}{l}\text { Cerrahiyi tolere } \\
\text { edemez }\end{array}$ & Konvansiyonel radyoterapi \\
\hline $\begin{array}{l}\text { Yüksek evreli epidural spinal kord } \\
\text { kompresyonu }\end{array}$ & Radyorezistan & Stabil değil & $\begin{array}{l}\text { Cerrahiyi tolere } \\
\text { edebilir }\end{array}$ & $\begin{array}{l}\text { Dekompresyon/stabilizasyon ve takiben } \\
\text { stereotaktik radyoterapi }\end{array}$ \\
\hline $\begin{array}{l}\text { Yüksek evreli epidural spinal kord } \\
\text { kompresyonu }\end{array}$ & Radyorezistan & Stabil değil & $\begin{array}{l}\text { Cerrahiyi tolere } \\
\text { edemez }\end{array}$ & $\begin{array}{l}\text { Stabilizasyon ve takiben konvansiyonel } \\
\text { radyoterapi }\end{array}$ \\
\hline
\end{tabular}




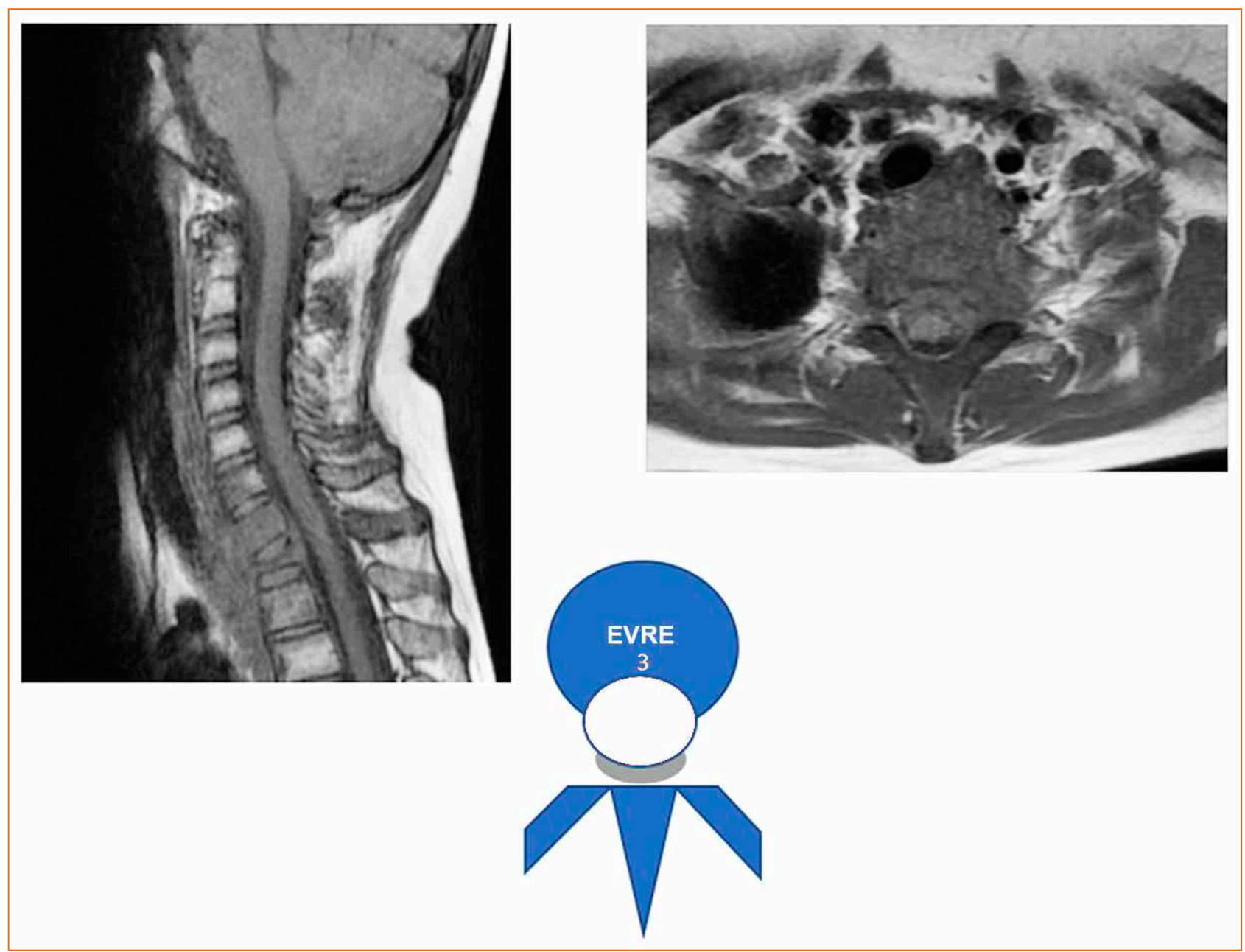

Şekil 5. NOMS çatısına göre hasta tedavi planlaması.

kemik metastazlı ve ağrılı hastalarda, özellikle radyoaktif iyodin $\left(\mathrm{I}^{125}\right)$ tanelerinin bir kanül yardımıyla kemik içine yerleştirilmesiyle, yüksek doz radyasyon düzeyine lokal olarak ulaşıımış olur. Brakiterapi dozunun \%95'i patolojik dokuya $8-10$ ay içinde verilmiş olur. ${ }^{[17]}$

Palyatif radyoterapiye uygun olmayan, çoklu metastazlı ve yaygın ağrıları olan hastalarda, radyoizotoplar kullanılarak diğer bir radyoterapi türü uygulanır. Strontium 86, samarium 153 ve rhenium 186, artmış osteoblastik aktiviteli alanlara selektif olarak radyasyon iletimini sağlar. İki aydan az yaşam beklentisi durumunda, yaygın yumuşak doku metastazları varlığında, trombosit sayısının $60.000 / \mathrm{mm}^{3}$ altında olduğu durumlarda ve kısa bir süre önce trombosit sayısındaki ani düşüş olduğunda; yine, 2.500'ün altında beyaz hücre sayısı ve yaygın intravasküler koagülasyon varlığında, miyelosupresif kemoterapinin ilk 1. ayında ve patolojik kırık ile spinal kord kompresyonu varlığında radyoizotop tedavisi uygulanmaz. ${ }^{[18,19]}$

Radyoaktif iyodin $\left(\mathrm{I}^{131}\right)$ tedavisi uzun zamandan beri, hem tiroid bezinin tümör cerrahisi sonrası arta kalan tümöral hücrelerin hem de tiroid kanserli hastalarda metastatik odakların ortadan kaldırılması için etkin bir tedavi olarak uygulanmaktadır. ${ }^{[20]}$

Konvansiyonel X ışını kullanılarak yapılan radyoterapinin yanı sıra, dünyada az sayıdaki merkezde proton veya karbon iyonları kullanılarak yapılan proton veya karbon iyon radyoterapisi (partikül bazlı radyoterapi) kondrosarkom ve kordoma gibi radyoterapiye dirençli primer kemik tümörlerinin tedavisinde oldukça etkin ve başarılı sonuçlar verse de; solid organların (akciğer, karaciğer, böbrek, vb.) kemiklere olan metastazlarının tedavisinde konvansiyonel radyoterapiye göre ek avantajları bulunmamaktadır. ${ }^{[21]}$ Genel bilgi olarak: 
konvansiyonel $\mathrm{X}$ ışını bazlı radyoterapide, $\mathrm{X}$ ışını ciltten itibaren enerjisi azalarak yol alır. Böylece, tümöral dokuya ulaşıncaya kadar enerjisi oldukça düşer. Partikül bazlı radyoterapide ise, proton ya da karbon iyon tümöral dokuya ulaşana dek maksimum enerjiyi taşımaya devam eder, tümöral dokuya ulaşınca neredeyse bütün enerjisini orada serbest bırakır. ${ }^{[22]}$

Metastatik kemik lezyonlu hastaların tedavisinde karar verirken; ortopedi ve travmatoloji uzmanı onkologlar ile medikal ve radyasyon onkologlarının multidispliner yaklaşımının önemi unutulmamalı ve plansız cerrahi girişim yapılmamalıdır. Hastalarda uygulanacak tedavi yaklaşımında radyoterapi; uzun kemiklerin metastatik lezyonlarında Mirels skorlama sistemine göre, vertebral metastazlarda ise NOMS çatısına göre belirlenmelidir. Radyoterapi, metastazlı hastalarda kırık kaynamasını engellemek bir yana, tümör hücrelerini yok ederek kaynama için uygun ortamı hazırlar.

Teknolojideki gelişmelere paralel olarak; tümör dokusu maksimum radyasyon dozunu alırken, sağlam dokuların minimum zarar görmesi yönündeki hedeflere ulaşmada ciddi adımlar atılmaktadır. Böylece, hastaların tedavisinin etkinliği artmakta ve gözlenen yan etkiler de azalmaktadır.

\section{KAYNAKLAR}

1. Hernandez RK, Wade SW, Reich A, Pirolli M, Liede A, Lyman $\mathrm{GH}$. Incidence of bone metastases in patients with solid tumors: analysis of oncology electronic medical records in the United States. BMC Cancer 2018;18(1):44. Crossref

2. Ogura K, Gokita T, Shinoda Y, Kawano H, Takagi T, Ae K, Kawai A, Wedin R, Forsberg JA. Can a multivariate model for survival estimation in skeletal metastases (PATHFx) be externally validated using Japanese patients? Clin Orthop Relat Res 2017;475(9):2263-70. Crossref

3. Forsberg JA, Wedin R, Boland PJ, Healey JH. Can we estimate short- and intermediate-term survival in patients undergoing surgery for metastatic bone disease? Clin Orthop Relat Res 2017;475(4):1252-61. Crossref

4. Piccioli A, Spinelli MS, Forsberg JA, Wedin R, Healey JH, Ippolito V, Daolio PA, Ruggieri P, Maccauro G, Gasbarrini A, Biagini R, Piana R, Fazioli F, Luzzati A, Di Martino A, Nicolosi F, Camnasio F, Rosa MA, Campanacci DA, Denaro V, Capanna R. How do we estimate survival? External validation of a tool for survival estimation in patients with metastatic bone disease-decision analysis and comparison of three international patient populations. BMC Cancer 2015;15:424. Crossref

5. De Felice F, Piccioli A, Musio D, Tombolini V. The role of radiation therapy in bone metastases management. Oncotarget 2017;8(15):25691-9. Crossref

6. Hartsell WF, Scott CB, Bruner DW, Scarantino CW, Ivker RA, Roach M 3rd, Suh JH, Demas WF, Movsas B, Petersen IA, Konski AA, Cleeland CS, Janjan NA, DeSilvio $M$. Randomized trial of short- versus long-course radiotherapy for palliation of painful bone metastases. J Natl Cancer Inst 2005;97(11):798-804. Crossref
7. Foro Arnalot P, Fontanals AV, Galcerán JC, Lynd F, Latiesas XS, de Dios NR, Castillejo AR, Bassols ML, Galán JL, Conejo IM, López MA. Randomized clinical trial with two palliative radiotherapy regimens in painful bone metastases: 30 Gy in 10 fractions compared with 8 Gy in single fraction. Radiother Oncol 2008;89(2):150-5. Crossref

8. Steenland $E$, Leer JW, van Houwelingen $H$, Post WJ, van den Hout WB, Kievit J, de Haes H, Martijn H, Oei B, Vonk E, van der Steen-Banasik E, Wiggenraad RG, Hoogenhout J, Wárlám-Rodenhuis C, van Tienhoven G, Wanders R, Pomp J, van Reijn M, van Mierlo T, Rutten E. The effect of a single fraction compared to multiple fractions on painful bone metastases: a global analysis of the Dutch Bone Metastasis Study. Radiother Oncol 1999;52(2):101-9. Crossref

9. Chow E, Zeng L, Salvo N, Dennis K, Tsao M, Lutz S. Update on the systematic review of palliative radiotherapy trials for bone metastases. Clin Oncol (R Coll Radiol) 2012;24(2):112-24. Crossref

10. Lutz S, Berk L, Chang E, Chow E, Hahn C, Hoskin P, Howell D, Konski A, Kachnic L, Lo S, Sahgal A, Silverman L, von Gunten C, Mendel E, Vassil A, Bruner DW, Hartsell W. Palliative radiotherapy for bone metastases: an ASTRO evidence-based guideline. Int J Radiat Oncol Biol Phys 2011;79(4):965-76. Crossref

11. van der Linden $Y M$, Lok JJ, Steenland E, Martijn $H$, van Houwelingen $\mathrm{H}$, Marijnen CAM, JWH Leer. Dutch Bone Metastasis Study Group. Single fraction radiotherapy is efficacious: a further analysis of the Dutch Bone Metastasis Study controlling for the influence of retreatment. Int J Radiat Oncol Biol Phys 2004;59(2):528-37. Crossref

12. Palma DA, Salama JK, Lo SS, Senan S, Treasure T, Govindan R, Weichselbaum R. The oligometastatic state --separating truth from wishful thinking. Nat Rev Clin Oncol 2014;11(9):54957. Crossref

13. Mirels H. Metastatic disease in long bones. A proposed scoring system for diagnosing impending pathologic fractures. Clin Orthop Relat Res 1989;(249):256-64. Crossref

14. Bhattacharya IS, Hoskin PJ. Stereotactic body radiotherapy for spinal and bone metastases. Clin Oncol (R Coll Radiol) 2015;27(5):298-306. Crossref

15. Laufer I, Rubin DG, Lis E, Cox BW, Stubblefield MD, Yamada $\mathrm{Y}$, Bilsky $\mathrm{MH}$. The NOMS framework: approach to the treatment of spinal metastatic tumors. Oncologist 2013;18(6):744-51. Crossref

16. Chow E, van der Linden $\mathrm{YM}$, Roos D, Hartsell WF, Hoskin $\mathrm{P}, \mathrm{Wu}$ JS, Brundage MD, Nabid A, Tissing-Tan CJ, Oei B, Babington S, Demas WF, Wilson CF, Meyer RM, Chen BE, RK Wong $S$. Single versus multiple fractions of repeat radiation for painful bone metastases: a randomised, controlled, noninferiority trial. Lancet Oncol 2014;15(2):164-71. Crossref

17. Feng S, Wang L, Xiao Z, Maharjan R, Chuanxing L, Fujun $Z$, Jinhua H, Peihong W. 125 I seed implant brachytherapy for painful bone metastases after failure of external beam radiation therapy. Medicine (Baltimore) 2015;94(31):e1253. Crossref

18. Skóra T, Kowalska $T$, Zawiła K. Effectiveness of radioisotope therapy in bone metastases, based on personal experience. Contemp Oncol (Pozn) 2012;16(3):201-5. Crossref

19. Montesano T, Giacomobono S, Acqualagna G, Colandrea M, Di Nicola A, Travascio L, Giancamerla M, D'Apollo R, Toteda M, Ugolini F, Filesi M, Ronga G. Our experience on pain palliation of bone metastasis with $\mathrm{Sr}-89$ or $\mathrm{Sm}-153$ in cancer patients resistant to a conventional analgesic therapy. A retrospective study. Clin Ter 2009;160(3):193-9. 
20. Cooper DS, Doherty GM, Haugen BR, Kloos RT, Lee SL, Mandel SJ, Mazzaferri EL, Mclver B, Pacini F, Schlumberger M, Sherman SI, Steward DL, Tuttle RM; American Thyroid Association (ATA) Guidelines Taskforce on Thyroid Nodules and Differentiated Thyroid Cancer. Revised American Thyroid Association management guidelines for patients with thyroid nodules and differentiated thyroid cancer. Thyroid 2009;19(11);1167-214. Crossref

21. Snider JW, Schneider RA, Poelma-Tap D, Stieb S, Murray FR, Placidi L, Albertini F, Lomax A, Bolsi A, Kliebsch U, Malyapa $\mathrm{R}$, Weber DC. Long-term outcomes and prognostic factors after pencil-beam scanning proton radiation therapy for spinal chordomas: A large, single-institution cohort. Int J Radiat Oncol Biol Phys 2018;101(1):226-33. Crossref
22. Demizu $Y$, Jin D, Sulaiman NS, Nagano $F$, Terashima $K$, Tokumaru S, Akagi T, Fujii O, Daimon T, Sasaki R, Fuwa N, Okimoto T. Particle therapy using protons or carbon ions for unresectable or incompletely resected bone and soft tissue sarcomas of the pelvis. Int J Radiat Oncol Biol Phys 2017;98(2):367-74. Crossref 